\title{
排ガス循環型酸素燃焼および熱循環型高温空気燃焼の熱力学的観点からの比較
}

\author{
佐藤 賢一 ${ }^{* 1}$, 藤田 修*2
}

\section{Comparison of thermodynamical potentials of oxy-fuel combustion and regenerative combustion}

\author{
Kenichi SATO ${ }^{* 1}$ and Osamu FUJITA ${ }^{* 2}$ \\ ${ }^{*},{ }^{*}{ }_{2}$ Fuculty of Engineering, Hokkaido University \\ Kita 13, Nishi 8, Kita-ku, Sapporo, Hokkaido 060-8628, Japan
}

Received: 4 February 2018; Revised: 14 April 2018; Accepted: 16 August 2018

\begin{abstract}
Possibility of the higher combustion efficiency using the oxy-fuel combustion technology has been studied from the thermodynamic point of view. The energy consumption and the change in entropy were calculated for the case of the normal air combustion, the regenerative combustion, and the oxy-fuel combustion. The energy consumption and the change in entropy were compared and discussed for three cases. For the oxy-fuel combustion, the energy required to produce the pure oxygen from the air was considered. The regenerative combustion was the case in consideration of a heat recovery. As a result, the thermodynamical potential of the oxy-fuel combustion is higher than that of the normal air combustion when the exhaust gas temperature is high. The thermodynamical potential of the regenerative combustion depends on the heat recovery efficiency of the regenerative system. The thermodynamical potential of the oxy-fuel combustion is lower than that of the regenerative combustion for the lower exhaust gas temperature, but for the higher exhaust temperature that of the oxy-fuel combustion is higher than that of the regenerative combustion.
\end{abstract}

Keywords : Oxygen combustion, Oxy-fuel combustion, Entropy, Enthalpy, Normal air combustion, Regenerative combustion

\section{1. 緒言}

近年，地球温暖化が世界的に大きな問題となり，各国で温暖化ガスの一つである二酸化炭素の大気中への放出 削減に向けた様々な努力がなされている. 我が国においても 2015 年のパリでの COP21 をふまえ, 2030 年度に二 酸化炭素の排出を 2013 年度に比べて $26 \%$ 削減する中期目標が定められ, さらに長期的目標として 2050 年までに $80 \%$ 二酸化炭素の削減を目指寸ことが位置づけられている(環境省，2016).これらの目標の達成のためには, 発電において二酸化炭素を排出しない再生可能エネルギーの大量導入が重要であるがそれだけでは不十分で，火 力発電所の高効率化, 自動車や各種機器の高効率化による省エネルギー, さらには二酸化炭素回収貯留(CCS: Carbon Dioxide Capture and Storage)技術の開発が求められている. 日本の二酸化炭素排出の $33 \%$ \%産業部門から の排出であり，その内の約 $20 \%$ 加熱などに使われる工業炉からの排出である. したがって，産業部門からの排 出を低減させるためには，工業炉の高効率化による二酸化炭素の排出抑制が大切である．工業炉の高効率化をは かるため, 経済産業省/新エネルギー・産業技術総合開発機構（NEDO）主導で「高性能工業炉の開発」プロジェ クトが 1993 年から 1999 年にかけて行われ，熱循環型高性能工業炉が開発された(NEDO, 2012).これは，リジェ

No.18-00070 [DOI:10.1299/transjsme.18-00070], J-STAGE Advance Publication date : 30 August, 2018

${ }^{* 1}$ 正員, 北海道大学大学院工学院（下060-8628 北海道札幌市北区北 13 条西 8 丁目）

*2 正員, フェロー, 北海道大学大学院工学研究院

E-mail of corresponding author: ofujita@eng.hokudai.ac.jp 
ネバーナシステムを用いた炉で，リジェネ炉と呼ばれ 30 \%以上の省エネルギーと低 $\mathrm{NO}_{\mathrm{x}}$ 化を実現させたもので ある. 現在, さらなる熱効率向上による省エネルギー達成のため, 熱循環型だけでなく, 酸素燃焼や酸素燃焼と 熱循環を組み合わせた炉の検討が始まっている，そこで本研究では，熱循環型高温空気燃焼炉および排ガス循環 型酸素燃焼炉について熱力学観点から比較検討を行うことにした.

熱循環型燃焼炉については，先に述べた高性能工業炉の開発プロジェクトで多くの研究が行われた(NEDO, 2012, Katsuki and Hasegawa, 1998, Fujimori et al., 2000, Tsuji et al., 2003). 熱循環型燃焼炉の概念は新しいものではな く，これまでに通常の熱交換器を用いた炉が省エネルギーのために広く利用されてきた．この場合熱交換器の耐 熱性のため, 高温排気ガスの熱を回収して供給空気を加熱する程度が 600〜 $800 \mathrm{~K}$ 程度に制限され, 大幅な熱効率 の向上には結びついていなかった，それに対し，蓄熱型熱交換器を用い空気を簡便に $1100 \mathrm{~K}$ 以上に加熱する技術 が開発され，さらにそれによる高温空気を用いて低 $\mathrm{NO}_{\mathrm{x}}$ 燃焼を行う新しい燃焼方法が研究された(Katsuki and Hasegawa, 1998, Fujimori et al., 2000, Tsuji et al., 2003). これにより，大幅な熱効率の向上と従来以上の低 $\mathrm{NO}_{\mathrm{x}}$ 排出 を両立した加熱炉が開発された．この熱循環型燃焼炉については，これまでに熱力学の第一法則だけでなく第二 法則を考慮した熱力学的検討が丸田および吉澤により行われている(丸田,2007, 吉澤, 2008). 丸田は, 燃料・燃焼 系のエクセルギーに関する吉田の検討(吉田, 1999), 燃焼過程におけるエクセルギー損失に関する西田らの検討(西 田他, 2002)をもとに, 熱循環型燃焼炬に対して考察を行った(丸田, 2007). その結果, 空気を高温に予熱する熱循 環型燃焼炉, 通称リジェネ炉は, 燃焼過程におけるエントロピー増加が少なく, 空気予熱温度が高くなるにつれ, エクセルギー効率が高くなることを示した．吉澤は，熱循環型燃焼についてエンタルピーおよびエントロピーの 変化について詳細に考察し, さらに加熱炉におけるエクセルギ一利用率について検討を行った(吉澤, 1994, 2008). その結果, 熱循環により加熱炉の熱利用温度まで空気および然料を予熱することにより, 利用可能なエクセルギ 一が大幅に増加することを示した.

酸素燃焼は，窯業などの超高温の工業炉などで古くから用いられてきた。これは酸素を用いることにより $2500 \mathrm{~K}$ を超えるような高温の燃焼ガスを容易に生成できるからである. 省エネルギーの観点, また空気中の窒素 が燃焼過程で $\mathrm{NO}_{\mathrm{x}}$ に変換されることを防止する観点から, 空気燃焼に代わり酸素燃焼の工業炉への利用がこれま で何度か検討された。しかし，酸素の製造コストを考慮すると経済的な成立は非常に難しく，これまでほとんど 実用化されてこなかった。一方，工業炉に非常に似ている炉としてボイラ火炉があるが，近年，石炭火力からの 二酸化炭素回収貯留(CCS)のために, 高濃度の二酸化炭素のみを排出寸る石炭燃焼炉として, 循環型酸素燃焼の適 用が提案され, 多くの研究が行われてきている(Liu and Okazaki, 2003, Buhre et al., 2005, Fujimori and Yamada, 2013).

Liu と Okazaki, Buhre ら, Fujimori と Yamada は, 循環型酸素燃焼に対し, それぞれの方法で実験的な研究を行 い, 循環型酸素燃焼を行うことによって, 従来型の石炭燃焼に比べて $\mathrm{NO}_{\mathrm{x}}$ と $\mathrm{SO}_{\mathrm{x}}$ を大幅に低減させることがで きることを示した，また，エネルギーバランス的にも排ガス循環で熱を循環させているので, 酸素製造および二 酸化炭素分離回収も含めた総合効率の低下は, 従来型の石炭燃焼炉に比べて $5 \%$ 程度であることを示した. 一方, Liu らは，バイオガスの酸素燃焼に関し，燃焼過程におけるエントロピーの生成を調べ，循環型酸素燃焼を想定 すると酸素は二酸化炭素および水蒸気で希釈されるが，その場合のエントロピーの生成は二酸化炭素で希釈した 場合の方が窒素で希釈した場合に比べ少ないことを示した(Liu et al., 2015).

これまでの研究では，以上に述べたように，熱循環型燃焼および循環型酸素燃焼に対し，熱力学の第一法則 および第二法則を用いた熱力学検討による比較検討が統一的になされているとは言い難い. そこで本研究では, 工業加熱炉のモデルを用い, 通常空気燃焼, 熱循環型高温空気燃焼および排ガス循環型酸素燃焼の熱力学的な比 較を同条件で行い，それぞれの熱力学的特徵および優れた点を明らかにすることにした.

\section{2.＼cjkstart計算モデルと計算方法}

図 1 に工業加熱炉をモデルとして, (a)通常空気燃焼, (b)熱循環型高温空気燃焼および(c)排ガス循環型酸素燃焼 の概念図を示す，いずれの燃焼方式においても，入口から酸化剤と燃料を入れ，炉内で燃焼させて被熱物に熱を 与えた後, 排ガスを炉外に排出する. 通常空気燃焼では燃料と空気を炉内で燃焼させた後, 炬内で生成される排 ガスは，そのまますべて炉外一排出される．計算では，炉内温度を炉内に入れる空気の量で調整した．熱循環型 高温空気燃焼では，近年の工業加熱炉で飛躍的な熱効率を誇るリジェネレーティブバーナ方式を仮定した．これ 


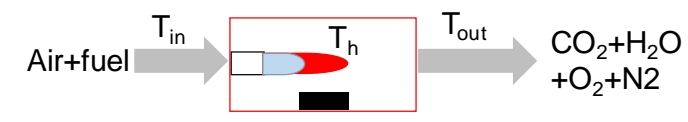

(a)Normal air combustion

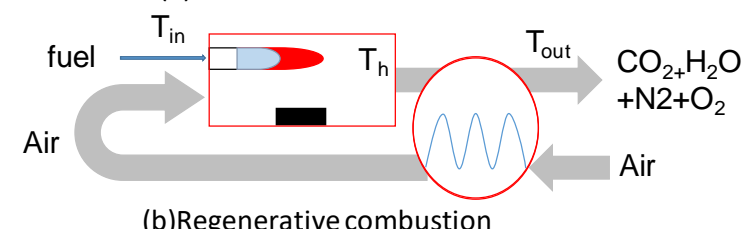

(b)Regenerative combustion

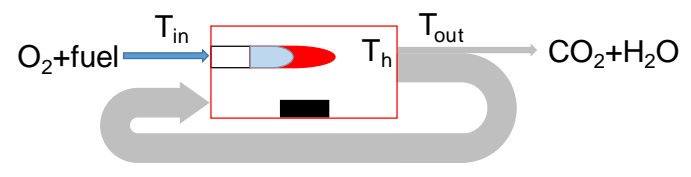

$\mathrm{CO}_{2}+\mathrm{H}_{2} \mathrm{O}$

(c)Oxy-fuel combustion

Fig. 1 Calculation models

は，片方のバーナが作動している時にもう片方のバーナ内の蓄熱器で熱をため込み，ある程度の熱が蓄熱できた らもう片方のバーナを作動させ，蓄熱器にため込まれた熱で然焼用空気を予熱する方式である，計算では，炉内 温度を予熱した空気の量で調整した，排ガス循環型酸素燃焼では，純酸素と燃料を大気温度で炉内に投入し燃焼 させ, 排ガスの二酸化炭素および水蒸気の一部を, 温度を下げることなく炉内に入れて再循環させる. 計算では, 炉内温度を，炉内へ排ガスを再循環させる量で調整した。

いずれの燃焼方式においても燃料はメタンとし, メタンが完全燃焼した時の発熱量を $50.1 \mathrm{MJ} / \mathrm{kg}$ (日本物理学会, 2006)として計算を行った. メタンの反応式は式(1)で表される.

$$
\mathrm{CH}_{4}+2 \mathrm{O}_{2} \rightarrow \mathrm{CO}_{2}+2 \mathrm{H}_{2} \mathrm{O}
$$

通常空気燃焼の場合, 燃料 $1 \mathrm{~kg}$ を燃焼した際の投入エネルギーと生成されるエントロピーは式(2)および式(3) のように表すことができる.

$$
\begin{aligned}
& \mathrm{Q}=\mathrm{G}_{\mathrm{CO} 2} \int_{\mathrm{T}_{\mathrm{in}, 0}}^{\mathrm{T}_{\mathrm{h}}} \mathrm{Cp}_{\mathrm{CO} 2} \mathrm{dT}+\mathrm{G}_{\mathrm{H} 2 \mathrm{O}} \int_{\mathrm{T}_{\mathrm{in}, 0}}^{\mathrm{T}_{\mathrm{h}}} \mathrm{Cp}_{\mathrm{H} 2 \mathrm{O}} \mathrm{dT}+\mathrm{G}_{\mathrm{O} 2} \int_{\mathrm{T}_{\mathrm{in}, 0}}^{\mathrm{T}_{\mathrm{h}}} \mathrm{Cp}_{\mathrm{O} 2} \mathrm{dT}+\mathrm{G}_{\mathrm{N} 2} \int_{\mathrm{T}_{\mathrm{in}, 0}}^{\mathrm{T}_{\mathrm{h}}} \mathrm{Cp}_{\mathrm{N} 2} \mathrm{dT} \\
& \Delta s=G_{\mathrm{CO} 2} \int_{\mathrm{T}_{\mathrm{in}, 0}}^{\mathrm{T}_{\mathrm{h}}} \frac{\mathrm{Cp}_{\mathrm{CO} 2}}{\mathrm{~T}} \mathrm{dT}+\mathrm{G}_{\mathrm{H} 2 \mathrm{O}} \int_{\mathrm{T}_{\mathrm{in}, 0}}^{\mathrm{T}_{\mathrm{h}}} \frac{\mathrm{Cp}_{\mathrm{H} 2 \mathrm{O}}}{\mathrm{T}} \mathrm{dT}+\mathrm{G}_{\mathrm{O} 2} \int_{\mathrm{T}_{\mathrm{in}, 0}}^{\mathrm{T}_{\mathrm{h}}} \frac{\mathrm{Cp}_{\mathrm{O} 2}}{\mathrm{~T}} \mathrm{dT}+\mathrm{G}_{\mathrm{N} 2} \int_{\mathrm{T}_{\mathrm{in}, 0}}^{\mathrm{T}_{\mathrm{h}}} \frac{\mathrm{Cp}_{\mathrm{N} 2}}{\mathrm{~T}} \mathrm{dT}
\end{aligned}
$$

ここで, $\mathrm{Q}$ は発熱量, $\mathrm{G}$ は各ガスの質量, $\mathrm{Cp}$ は各比熱, $\mathrm{T}_{\mathrm{h}}$ は炉内温度, $\mathrm{T}_{\mathrm{in}, 0}$ は大気温度, $\Delta \mathrm{s}$ はエントロピ 一である. 通常空気燃焼の場合, 式(1)を用いてメタン $1 \mathrm{~kg}$ が完全燃焼したときの二酸化炭素の質量 $\mathrm{G}_{\mathrm{CO} 2}$ および 水蒸気の質量 $\mathrm{G}_{\mathrm{H} 2 \mathrm{O}}$ を求め, その結果を用いて, 式(2)から炉内温度が $\mathrm{T}_{\mathrm{h}}$ になるような各ガス成分の質量を求めた. さらに，式(3)を用いてエントロピー $\Delta \mathrm{s}$ を算出した.

熱循環型高温空気燃焼の場合，燃料は空気温度と同じ温度に予熱されると仮定した．予熱された空気および燃 料を炉内温度 $\mathrm{T}_{\mathrm{h}}$ まで上昇させた時のエネルギーおよびエントロピー $\triangle \mathrm{s}$ は式(4), 式(5)および式(6)で表すことが できる．なおこの式ではでは $\mathrm{G}_{\mathrm{O} 2}, \mathrm{G}_{\mathrm{N} 2}$ は炉内に入る予熱された $\mathrm{O}_{2}$ およ゙ $\mathrm{N}_{2}$ の質量流量を意味している.

$$
\begin{aligned}
& \mathrm{Q}=\mathrm{G}_{\mathrm{CO} 2} \int_{\mathrm{T}_{\mathrm{in}, 1}}^{\mathrm{T}_{\mathrm{h}}} \mathrm{Cp}_{\mathrm{CO} 2} \mathrm{dT}+\mathrm{G}_{\mathrm{H} 2 \mathrm{O}} \int_{\mathrm{T}_{\mathrm{in}, 1}}^{\mathrm{T}_{\mathrm{h}}} \mathrm{Cp}_{\mathrm{H} 2 \mathrm{O}} \mathrm{dT}+\mathrm{G}_{\mathrm{O} 2} \int_{\mathrm{T}_{\mathrm{in}, 1}}^{\mathrm{T}_{\mathrm{h}}} \mathrm{Cp}_{\mathrm{O} 2} \mathrm{dT}+\mathrm{G}_{\mathrm{N} 2} \int_{\mathrm{T}_{\mathrm{in}, 1}}^{\mathrm{T}_{\mathrm{h}}} \mathrm{Cp}_{\mathrm{N} 2} \mathrm{dT}
\end{aligned}
$$

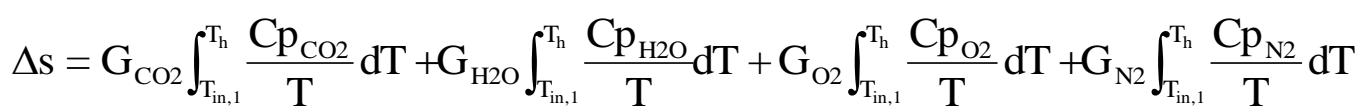




$$
\eta=\frac{\mathrm{T}_{\mathrm{in}, 1}-\mathrm{T}_{\mathrm{in}, 0}}{\mathrm{~T}_{\mathrm{out}}-\mathrm{T}_{\mathrm{in}, 0}}
$$

ここで， $\mathrm{T}_{\mathrm{in}, 1}$ は予熱した空気および然料の温度， $\mathrm{T}_{\text {out }}$ は炉からの排ガス温度， $\eta$ は式(6)により定義した排熱回収 率である．排熱回収率 $\eta$ は熱循環型高温空気然焼において排熱の回収の程度を温度に基づいて与えたもので，排 ガス温度を用いて予熱空気を作る時の効率を表している. 熱循環型高温空気燃焼の場合, 式(1)および式(4)から求 めた予熱される酸素および窒素の質量を合算したものを作動流体質量 $\mathrm{G}_{\mathrm{gas}}$ とした. さらに，式(5)を用いエントロ ピー $\Delta \mathrm{s}$ を算出した. 式(4)および式(5)で用いられる予熱した空気および然料の温度 $\mathrm{T}_{\mathrm{in}, 1}$ は式(6)で求められる.

排ガス循環型酸素燃焼の場合, 排ガスの一部である二酸化炭素と水蒸気を再循環させる. そのため, 再循環さ せた排ガスの温度 $\mathrm{T}_{\text {out }}$ を炉内温度 $\mathrm{T}_{\mathrm{h}}$ まで上昇させる。したがって，再循環させる二酸化炭素と水蒸気の入口温度 $\mathrm{T}_{\mathrm{in}}$ は排ガス温度 $\mathrm{T}_{\text {out }}$ と同じである. 排ガス以外のメタンと酸素は大気温度 $\mathrm{T}_{\mathrm{in}, 0}$ から炉内温度 $\mathrm{T}_{\mathrm{h}}$ まで上昇させる. したがって，メタンと酸素が反応してできた二酸化炭素と水蒸気は大気温度 $\mathrm{T}_{\mathrm{in}, 0}$ から炉内温度 $\mathrm{T}_{\mathrm{h}}$ まで上昇する ことになる.

排ガス循環型酸素燃焼において，投入エネルギーおよびエントロピー $\triangle \mathrm{s}$ は式(7)および式(8)で表すことができ る.

$$
\begin{aligned}
& \mathrm{Q}=\mathrm{G}_{\mathrm{CO} 2} \int_{\mathrm{T}_{\mathrm{in}, 0}}^{\mathrm{T}_{\mathrm{h}}} \mathrm{Cp}_{\mathrm{CO} 2} \mathrm{dT}+\mathrm{G}_{\mathrm{H} 2 \mathrm{O}} \int_{\mathrm{T}_{\mathrm{in}, 0}}^{\mathrm{T}_{\mathrm{h}}} \mathrm{Cp}_{\mathrm{H} 2 \mathrm{O}} \mathrm{dT}+\mathrm{G}_{\mathrm{CO} 2, \mathrm{cir}} \int_{\mathrm{T}_{\mathrm{out}}}^{\mathrm{T}_{\mathrm{h}}} \mathrm{Cp}_{\mathrm{CO} 2} \mathrm{dT}+\mathrm{G}_{\mathrm{H} 2 \mathrm{O}, \mathrm{cir}} \int_{\mathrm{T}_{\text {out }}}^{\mathrm{T}_{\mathrm{h}}} \mathrm{Cp}_{\mathrm{H} 2 \mathrm{O}} \mathrm{dT}
\end{aligned}
$$

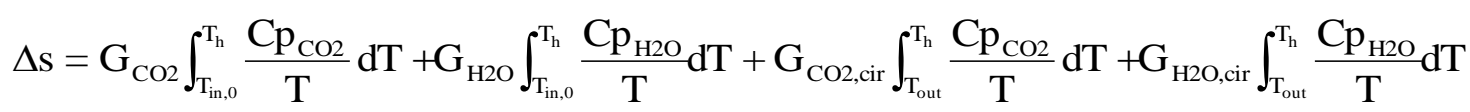

$$
\begin{aligned}
& \mathrm{G}_{\mathrm{CO} 2}: \mathrm{G}_{\mathrm{H} 2 \mathrm{O}}=44: 36
\end{aligned}
$$

ここで $\mathrm{G}_{\mathrm{CO} 2, \mathrm{cir}}$ は再循環する二酸化炭素の質量, $\mathrm{G}_{\mathrm{H} 2 \mathrm{O}, \mathrm{cir}}$ は再循環する水蒸気の質量を表す. 排ガス循環型酸素燃 焼の場合, 式(1)からメタン $1 \mathrm{~kg}$ が完全燃焼したときの二酸化炭素の質量および水蒸気の質量を求め, その結果を 用いて 式(7)と式(9)から再循環させる二酸化炭素および水蒸気の質量を求めた．さらに，式(8)からエントロピー $\triangle \mathrm{s}$ を算出した. すべての質量の合計を排ガス循環型酸素燃焼のガスの作動流体質量 $\mathrm{G}_{\mathrm{gas}}$ とした. なお，排ガス 循環型酸素燃焼と通常空気燃焼および熱循環型高温空気燃焼を比較するため, 排ガス循環型酸素燃焼において空 気から純酸素を分離する際に生じるエントロピーを考慮した. すなわち, $1 \mathrm{~kg}$ のメタンを完全燃焼させるのに必 要な酸素量 $4 \mathrm{~kg}$ と酸素製造の電力原単位から, 酸素製造に必要なエントロピーを求めた. 電力原単位 $\mathrm{W}$ は酸素 を作る時の消費電力で, 酸素製造を深冷分離法で行う場合の值である $0.3 \mathrm{kWh} / \mathrm{m}^{3} \mathrm{~N}$ を用いた (NEDO, 2011). ま た，酸素製造に用いる電力の効率は本計算では 0.55 とした.

\section{3. 結果および考察}

図 2 に炉内温度 $\mathrm{T}_{\mathrm{h}}$ が $1900 \mathrm{~K}$ の時の通常空気燃焼, 熱循環型高温空気燃焼および排ガス循環型酸素燃燒の各排 ガス温度 $\mathrm{T}_{\text {out }}$ における燃料メタン $1 \mathrm{~kg}$ を燃焼したときのエントロピー $\Delta \mathrm{s}$ を示す. 図中, 熱循環型高温空気燃焼

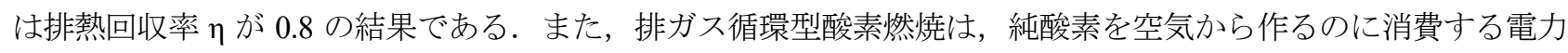
である電力原単位 $\mathrm{W}$ が $0 \mathrm{kWh} / \mathrm{m}^{3} \mathrm{~N}$ および $0.3 \mathrm{kWh} / \mathrm{m}^{3} \mathrm{~N}$ の時の結果である. 電力原単位 $\mathrm{W}$ が $0 \mathrm{kWh} / \mathrm{m}^{3} \mathrm{~N}$ は, 酸 素製造のエネルギーを考慮しない場合を意味する。なお，通常空気燃焼は熱循環型高温空気燃焼の排熱回収率 $\eta$ が 0 の場合と同じである.

通常空気燃焼の場合, エントロピー $\Delta \mathrm{s}$ は排ガス温度 $\mathrm{T}_{\text {out }}$ に関わらず一定である.これに対し, 熱循環型高温空 気燃焼および排ガス循環型酸素燃焼では，排ガス温度 $\mathrm{T}_{\text {out }}$ の上昇に伴いエントロピー $\Delta \mathrm{s}$ は小さくなる.これは, 熱循環型高温空気燃焼および排ガス循環型酸素燃焼ともに, 排ガス温度 $\mathrm{T}_{\text {out }}$ が高くなると, 予熱される空気, あ るいは再循環される二酸化炭素と水蒸気の熱量が増大寸るためである. 熱循環型高温空気燃焼と排力゙ス循環型酸 素燃焼を比べると, 排ガス循環型酸素燃焼のエントロピー $\Delta \mathrm{s}$ の方が熱循環型高温空気燃焼のそれよりも大きい. 


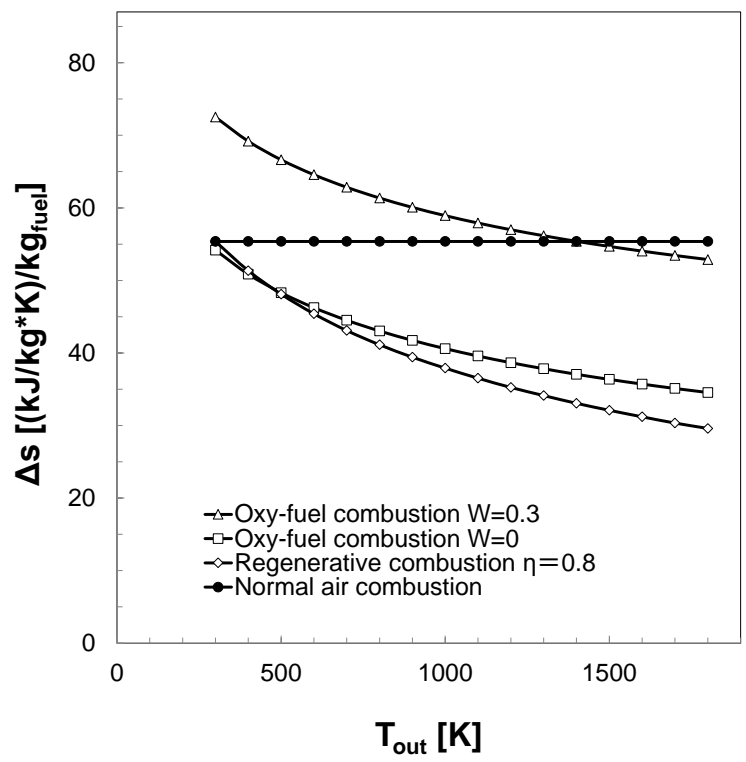

Fig. 2 Effect of outlet gas temperature on the entropy for the normal air combustion, the regenerative combustion, and the oxyfuel combustion when the furnace temperature $T_{h}=1900 \mathrm{~K}$. The power consumptions of the unit oxygen production $\mathrm{W}$ are 0 and $0.3 \mathrm{kWh} / \mathrm{m}^{3} \mathrm{~N}$ and the heat recovery efficiency $\eta$ is 0.8 .

これは，排ガス循環型酸素燃燒では，循環される排ガスである二酸化炭素と水蒸気の比熱が，熱循環型高温空 気燃焼で炉内投入される高温空気の比熱より大きく，排ガス温度 $\mathrm{T}_{\text {out }}$ から炉内温度 $\mathrm{T}_{\mathrm{h}}$ への加熱に多くの熱量を 必要とするためである。また，熱循環型高温空気燃焼および排ガス循環型酸素燃焼ともに排ガス温度 $\mathrm{T}_{\mathrm{out}}$ の上昇

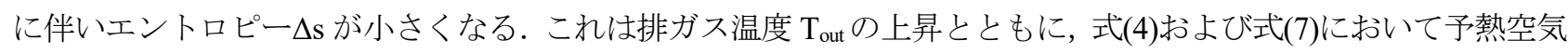
の量ならびに循環排ガスの量が増加するためである.

排ガス循環型酸素燃焼の $\mathrm{W}=0.3 \mathrm{kWh} / \mathrm{m}^{3} \mathrm{~N}$ の場合，排ガス温度 $\mathrm{T}_{\text {out }}$ が $300 \mathrm{~K}$ の時のエントロピー $\triangle \mathrm{s}$ は，通常空 気燃焼に比べて極めて大きい。これは，排ガス循環型酸素然焼では，酸素製造のために必要なエネルギーがエン トロピー $\Delta \mathrm{s}$ に含まれているからである。ただし，排ガス温度 $\mathrm{T}_{\text {out }}$ が $1400 \mathrm{~K}$ 以上になると， $\mathrm{W}=0.3 \mathrm{kWh} / \mathrm{m}^{3} \mathrm{~N}$ の場 合のエントロピー $\Delta \mathrm{s}$ は通常空気燃焼よりも小さくなる.また， $\mathrm{W}=0 \mathrm{kWh} / \mathrm{m}^{3} \mathrm{~N}$ すなわち酸素製造のエネルギーを 考慮しない場合には, 排ガス温度 $\mathrm{T}_{\text {out }}$ が $300 \mathrm{~K}$ の時のエントロピー $\Delta \mathrm{s}$ は通常空気燃焼の場合より若干小さい. こ れは炉内ガスの成分とその比熱の温度依存性によるもので，高温で比熱の大きなガス成分が多い排ガス循環型酸 素然焼の方がエントロピーの増加が僅かに小さくなるからである.

図 3 に炉内温度 $\mathrm{T}_{\mathrm{h}}$ が $1900 \mathrm{~K}$ の時の通常空気燃焼，熱循環型高温空気燃焼および排ガス循環型酸素燃焼の単位 作動流体質量を発生させる時のエネルギー $\mathrm{Q} / \mathrm{G}_{\mathrm{gas}}$ と排ガス温度 $\mathrm{T}_{\text {out }}$ の関係を示す．縦軸は投入エネルギー $\mathrm{Q}$ を作 動流体質量 $\mathrm{G}_{\mathrm{gas}}$ で割ったものである. 図中, 熱循環型高温空気燃焼は排熱回収率 $\eta$ が 0.8 の時, 排ガス循環型酸 素然焼は電力原単位 $\mathrm{W}$ が $0 \mathrm{kWh} / \mathrm{m}^{3} \mathrm{~N}$ および $0.3 \mathrm{kWh} / \mathrm{m}^{3} \mathrm{~N}$ の結果である. 図において，排ガス循環型酸素燃焼の $\mathrm{W}=0 \mathrm{kWh} / \mathrm{m}^{3} \mathrm{~N}$ と $\mathrm{W}=0.3 \mathrm{kWh} / \mathrm{m}^{3} \mathrm{~N}$ が同じ值をとるのは，燃料の燃焼による発熱量と排ガス循環量が両者で同じた めである.

通常空気燃焼では排ガス温度 $\mathrm{T}_{\text {out }}$ に関わらず $\mathrm{Q} / \mathrm{G}_{\mathrm{gas}}$ が一定であるのに対し，熱循環型高温空気燃焼および排ガ ス循環型酸素燃焼では， $\mathrm{Q} / \mathrm{G}_{\mathrm{gas}}$ は排ガス温度 $\mathrm{T}_{\text {out }}$ の上昇とともに減少する.

熱循環型高温空気燃焼の場合, $\mathrm{Q} / \mathrm{G}_{\mathrm{gas}}$ は通常空気燃焼のそれより小さく, また, 排ガス温度 $\mathrm{T}_{\text {out }}$ の上昇につれ, さらに減少していく。これは，排ガス温度 $\mathrm{T}_{\text {out }}$ が高くなるにつれて蓄熱器に多くの熱が蓄えられて空気の予熱温 度が上昇することにより，同じエネルギーで多くの作動流体を加熱できるためである.

排ガス循環型酸素燃焼の場合，排ガス温度 $T_{\text {out }}$ が低い領域では， $Q / G_{\text {gas }}$ は通常空気燃焼のそれよりも大きい. 排 ガス循環型酸素燃焼においては, 循環させる排ガスが二酸化炭素と水蒸気で構成されており, この比熱が通常空 気燃焼における空気より大きい. そのため, 排ガス温度 $\mathrm{T}_{\text {out }}$ が低い場合は，排ガス温度 $\mathrm{T}_{\text {out }}$ を炉内温度 $\mathrm{T}_{\mathrm{h}}$ まで上 げるのに必要な熱量が多いからである. Q/ $\mathrm{G}_{\text {gas }}$ が通常空気燃焼のそれよりも小さくなるのは, 排ガス温度 $\mathrm{T}_{\text {out }}$ が $900 \mathrm{~K}$ 以上においてである. 


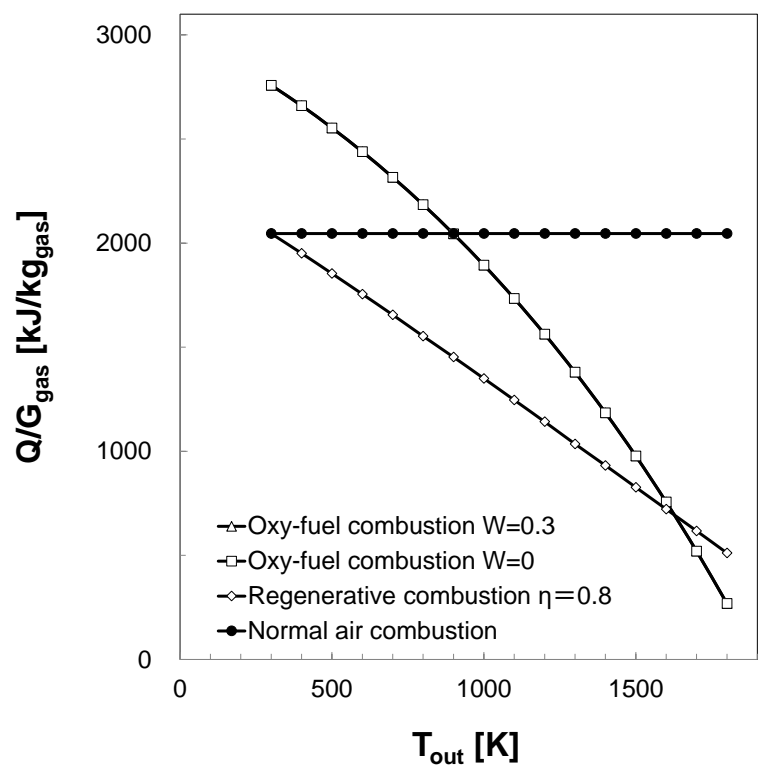

Fig. 3 Effect of outlet gas temperature on the input energy of the furnace for four cases when the furnace temperature

$$
\mathrm{T}_{\mathrm{h}}=1900 \mathrm{~K} \text {. }
$$

熱循環型高温空気燃焼と排ガス循環型酸素燃焼を比べると，排ガス温度 $\mathrm{T}_{\mathrm{out}}$ が $1700 \mathrm{~K}$ 以上になると，Q/G $\mathrm{G}_{\mathrm{gas}}$ は 排ガス循環型酸素燃焼の方が熱循環型高温空気燃焼よりも小さくなる．排ガス循環型酸素燃焼の場合，排ガスの 比熱が大きく，排ガス温度 $\mathrm{T}_{\text {out }}$ が高くなると循環によって炉内に戻される熱量が大きくなり，Q/G $\mathrm{G}_{\text {gas }}$ が排ガス温 度 $\mathrm{T}_{\text {out }}$ の上昇とともに急激に小さくなる。一方，熱循環型高温空気燃焼では熱回収率 $\eta$ を 0.8 と仮定している ため，排ガスの持つエネルギーのうち一定割合は排ガス温度 $\mathrm{T}_{\text {out }}$ に関わらず失われる. そのため，1700 K を超 える極めて高温の条件下では排ガス循環型酸素燃焼が有利な状況が現れてくる.ここで, 熱回収率 $\eta$ を 0.8 とし ているが，この值は熱循環型高温空気燃焼におけるほぼ最高の熱回収率である.

図 4 に炉内温度 $\mathrm{T}_{\mathrm{h}}$ が $1900 \mathrm{~K}$ の時の通常空気燃焼，熱循環型高温空気燃焼および排ガス循環型酸素燃焼の作動 流体質量 $\mathrm{G}_{\mathrm{gas}}$ と排ガス温度 $\mathrm{T}_{\mathrm{out}}$ の関係を示す。図中，熱循環型高温空気燃焼は排熱回収率 $\eta$ が 0.8 の時，排ガス 循環型酸素燃焼は電力原単位 $\mathrm{W}$ が $0 \mathrm{kWh} / \mathrm{m}^{3} \mathrm{~N}$ および $0.3 \mathrm{kWh} / \mathrm{m}^{3} \mathrm{~N}$ の時の結果である.

通常空気燃焼の場合，排ガス温度 $\mathrm{T}_{\text {out }}$ に関わらず作動流体質量 $\mathrm{G}_{\mathrm{gas}}$ が一定であるのに対し，排ガス循環型酸素 燃焼と熱循環型高温空気燃焼の場合には排ガス温度 $\mathrm{T}_{\text {out }}$ が上昇するにつれて作動流体質量 $\mathrm{G}_{\mathrm{gas}}$ は増加する.

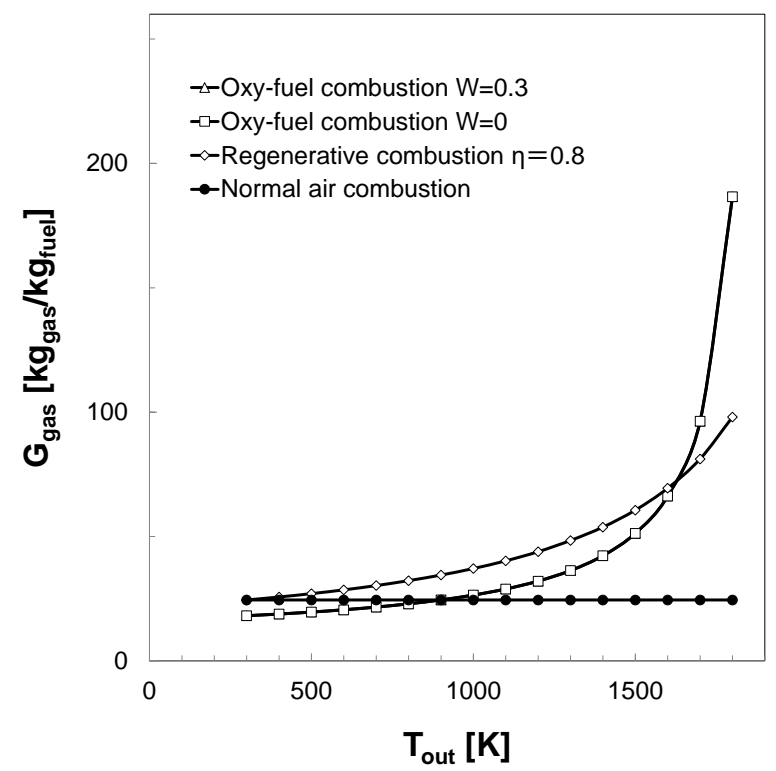

Fig. 4 Effect of outlet gas temperature on the unit working fluid when the furnace temperature $\mathrm{T}_{\mathrm{h}}=1900 \mathrm{~K}$. 
排ガス循環型酸素燃焼の場合, 排ガスである二酸化炭素と水蒸気を再循環させ，これを燃料の燃焼熱で排ガス 温度 $\mathrm{T}_{\text {out }}$ から炉内温度 $\mathrm{T}_{\mathrm{h}}$ まで温度上昇させるので, 排ガス温度 $\mathrm{T}_{\text {out }}$ の上昇とともに作動流体質量 $\mathrm{G}_{\mathrm{gas}}$ は大きくな る. 熱循環型高温空気燃焼の場合も同様に，蓄熱器であらかじめ予熱した空気を炉内に入れるため，同じエネル ギーを与えた場合に排ガス温度 $\mathrm{T}_{\text {out }}$ が高くなるほど作動流体質量 $\mathrm{G}_{\mathrm{gas}}$ が大きくなる. 排ガス温度 $\mathrm{T}_{\text {out }}$ がそれほど 高くない場合, 排ガス循環型酸素燃焼の作動流体質量 $\mathrm{G}_{\mathrm{gas}}$ は通常空気燃焼および熱循環型高温空気燃焼より小さ い. これは, 排ガス循環型酸素燃焼の作動流体ガスの比熱が, 空気よりも大きいためである.また, 排ガス温度 $\mathrm{T}_{\text {out }}$ が $1700 \mathrm{~K}$ を超える高温になると熱循環型高温空気燃焼よりも排ガス循環型酸素燃焼の方が作動流体質量 $\mathrm{G}_{\mathrm{gas}}$ は多くなる.これは, 熱循環型高温空気燃焼では排熱回収率 $\eta$ を 0.8 と仮定しているため, 極めて排ガス温度 $\mathrm{T}_{\text {out }}$ が高い条件では排ガス循環型酸素燃焼の方が熱回収が大きいためである.

図 5 に炉内温度 $\mathrm{T}_{\mathrm{h}}$ が $1900 \mathrm{~K}$ の時の通常空気燃焼, 熱循環型高温空気燃焼および排ガス循環型酸素燃焼の単位 作動流体質量を発生させる時のエントロピー変化 $\Delta \mathrm{s} / \mathrm{G}_{\mathrm{gas}}$ と排ガス温度 $\mathrm{T}_{\text {out }}$ の関係を示す. 図中, 熱循環型高温空 気燃焼は排熱回収率 $\eta$ が 0.8 の時, 排ガス循環型酸素燃焼は電力原単位 $\mathrm{W}$ が $0 \mathrm{kWh} / \mathrm{m}^{3} \mathrm{~N}$ および $0.3 \mathrm{kWh} / \mathrm{m}^{3} \mathrm{~N}$ の 時の結果である。

通常空気燃焼の場合, 排ガス温度 $\mathrm{T}_{\text {out }}$ に関わらず単位作動流体質量を発生させる時のエントロピー变化 $\Delta \mathrm{s} / \mathrm{G}_{\mathrm{gas}}$ は一定である。これに対し, 排ガス循環型酸素燃焼および熱循環型高温空気燃焼では排ガス温度 $\mathrm{T}_{\text {out }}$ の上昇とと もに $\Delta \mathrm{s} / \mathrm{G}_{\mathrm{gas}}$ は減少する。これは，図 4 で述べたように，排ガス温度 $\mathrm{T}_{\text {out }}$ が高くなるにつれ，排ガス循環型酸素燃 焼では同じエネルギーを与えた場合に多くの作動流体を発生させることができるため, 熱循環型高温空気燃焼で は空気の予熱温度が上昇することで同様に作動流体質量 $\mathrm{G}_{\mathrm{gas}}$ が増加するためである. また, 各ガスの比熱の温度 依存性も， $\Delta \mathrm{s} / \mathrm{G}_{\mathrm{gas}}$ の減少に寄与していると考えられる。

排ガス循環型酸素燃焼の場合, 排ガス温度 $\mathrm{T}_{\text {out }}$ が上昇するにつれて $\mathrm{W}=0.3 \mathrm{kWh} / \mathrm{m}^{3} \mathrm{~N}$ および $\mathrm{W}=0 \mathrm{kWh} / \mathrm{m}^{3} \mathrm{~N}$ の 時 $\Delta \mathrm{s} / \mathrm{G}_{\mathrm{gas}}$ の差が小さくなる. これは, 電力原単位 $\mathrm{W}$ のエントロピーが一定であるので, 作動流体質量 $\mathrm{G}_{\mathrm{gas}}$ が増 えると単位作動流体質量あたりのエントロピー $\Delta \mathrm{s} / \mathrm{G}_{\mathrm{gas}}$ の差が小さくなるためである.

一方, 排ガス温度 $\mathrm{T}_{\text {out }}$ が $1800 \mathrm{~K}$ 以上の高温になると, 熱循環型高温空気燃燒より排ガス循環型酸素燃焼の方が $\Delta \mathrm{s} / \mathrm{G}_{\mathrm{gas}}$ が小さくなる.これは, 熱循環型高温空気燃焼において排熱回収率 $\eta$ が存在するためであると考えられる. また, 排ガス循環型酸素燃焼の方が熱循環型高温空気燃焼に比べ, 高温になるにつれて発生する作動流体質量 $\mathrm{G}_{\mathrm{gas}}$ が大きくなることも要因の一つとして考えられる.

図 6 に通常空気燃焼および熱循環型高温空気燃焼時の排熱回収率 $\eta$ を $0.2 \sim 1.0$ まで変化させた場合の単位作動 流体質量あたりのエントロピー変化 $\Delta \mathrm{s} / \mathrm{G}_{\mathrm{gas}}$ と排ガス温度 $\mathrm{T}_{\text {out }}$ の関係を示寸. 炉内温度 $\mathrm{T}_{\mathrm{h}}$ は $1900 \mathrm{~K}$ である. なお, 通常空気燃焼は排熱回収率 $\eta$ が 0 と同等とみなすことができる.

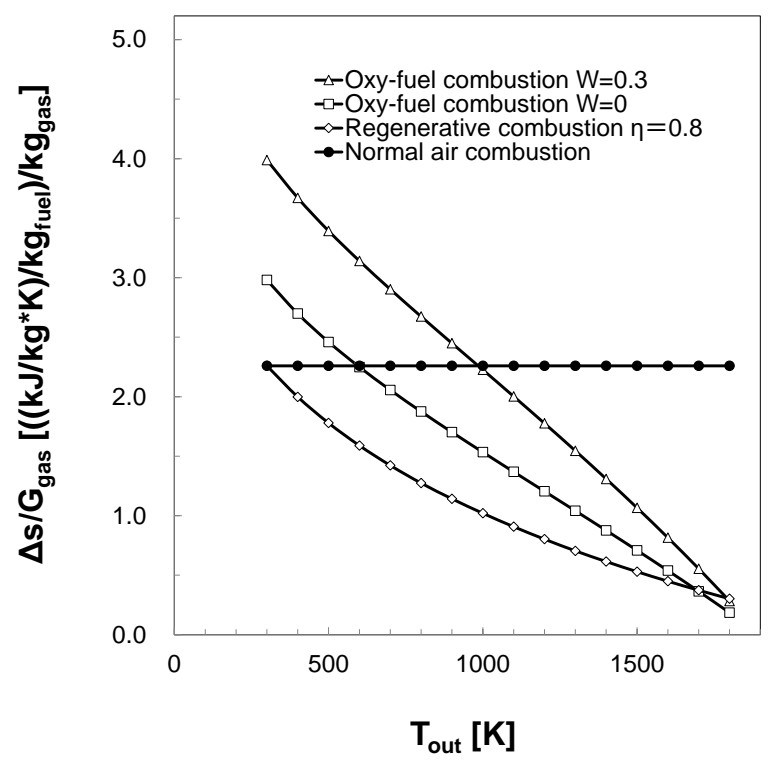

Fig. 5 Effect of outlet gas temperature on the entropy of the unit working fluid when the furnace temperature $T_{h}=1900 \mathrm{~K}$. 


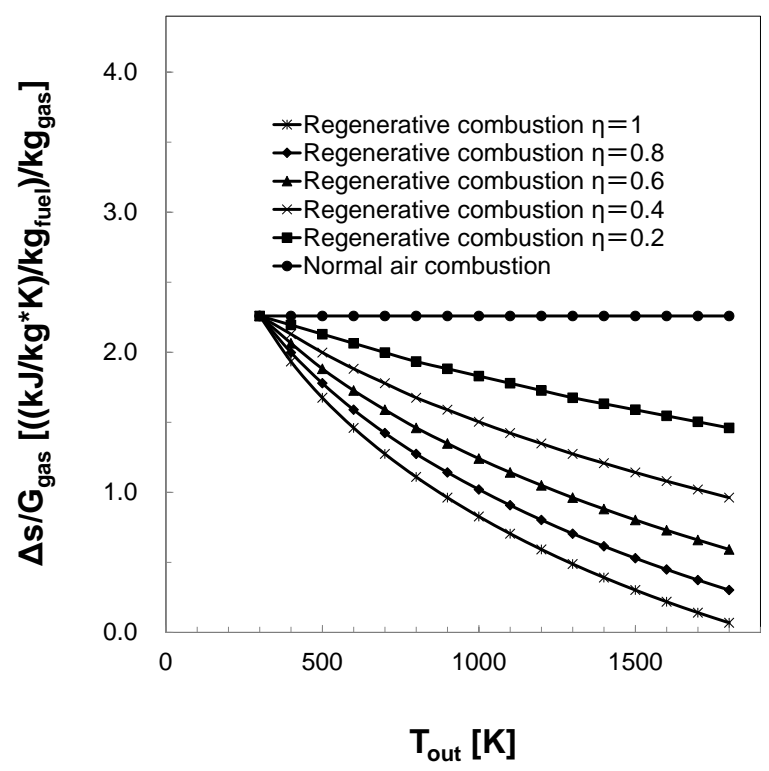

Fig. 6 Effect of the heat recovery efficiency and the outlet gas temperature on the entropy of the unit working fluid when the furnace temperature $T_{h}=1900 \mathrm{~K}$.

通常空気燃焼の場合は，排ガス温度 $\mathrm{T}_{\text {out }}$ に関わらず単位作動流体質量あたりのエントロピー変化 $\Delta \mathrm{s} / \mathrm{G}_{\mathrm{gas}}$ は一 定であるのに対し，熱循環型高温空気燃焼ではいずれの排熱回収率 $\eta$ においてもこの值は排ガス温度 $\mathrm{T}_{\text {out }}$ の上昇 とともに低下する。これは，排熱回収により空気を予熱できるためである.

一方，排熱回収率 $\eta$ が高くなるにつれ， $\Delta \mathrm{s} / \mathrm{G}_{\mathrm{gas}}$ は小さくなる．これは，排熱回収率 $\eta$ が高くなると空気の予熱 温度が上昇し，同じエネルギーを与えた場合，多くの作動流体を発生させることができるためである.

図 7 に, 排ガス循環型酸素然焼において, 炉内温度 $\mathrm{T}_{\mathrm{h}}$ が $1900 \mathrm{~K}$ の時の各電力原単位 $\mathrm{W}$ における単位作動流体 質量当たりのエントロピー変化 $\Delta \mathrm{s} / \mathrm{G}_{\mathrm{gas}}$ と排ガス温度 $\mathrm{T}_{\text {out }}$ の関係を表す.電力原単位 $\mathrm{W}$ が低下するにつれて $\Delta \mathrm{s} / \mathrm{G}_{\mathrm{gas}}$ は減少する。これは，空気から酸素を製造するためのエントロピーが減少するためである．排ガス温度 $\mathrm{T}_{\text {out }}$ が高 温になると電力原単位 $\mathrm{W}$ の影響は小さくなり，1800 K 付近では電力原単位 $\mathrm{W}$ の違いに関わらず， $\Delta \mathrm{s} / \mathrm{G}_{\mathrm{gas}}$ はほぼ 同じ值となる.

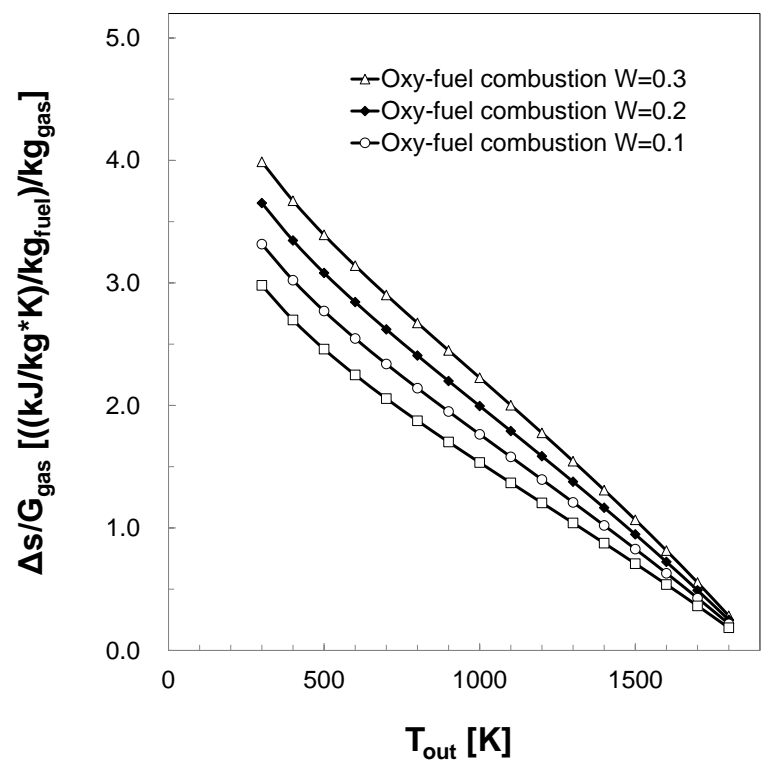

Fig. 7 Effect of the power consumption of the unit oxygen production and the outlet gas temperature on the entropy of the unit working fluid when the furnace temperature $\mathrm{T}_{\mathrm{h}}=1900 \mathrm{~K}$. 


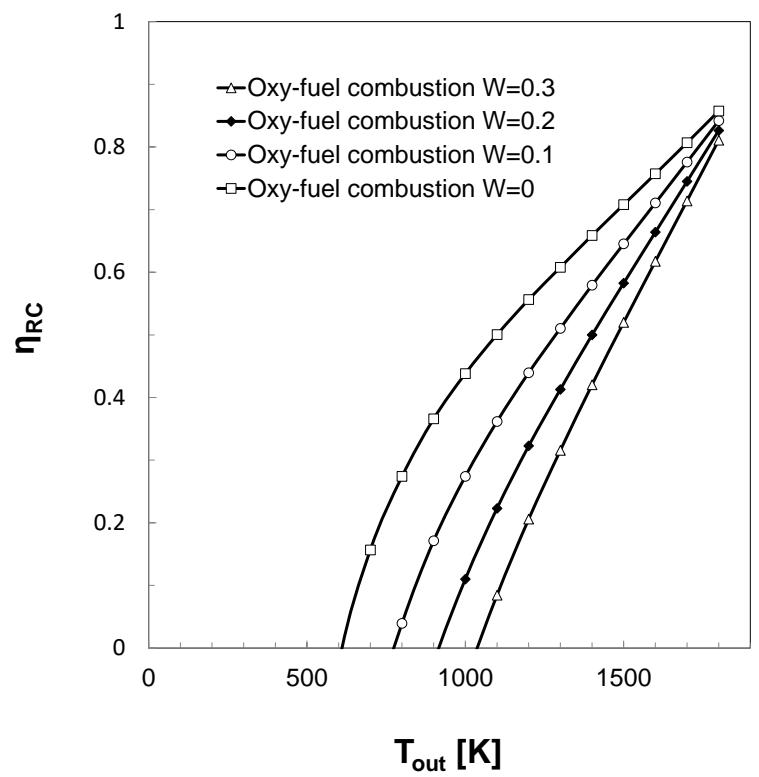

Fig. 8 Effect of outlet gas temperature on $\eta_{R C}$ when the furnace temperature $T_{h}=1900 \mathrm{~K}$. $\eta_{R C}$ represents the heat recovery efficiency for producing the equivalent entropy with the oxy-fuel combustion.

次に，熱循環型高温空気燃焼と排ガス循環型酸素燃焼のどちらが熱的に優れているのかを検討した．検討に当 たっては, 単位作動流体質量当たりのエントロピー変化 $\Delta \mathrm{s} / \mathrm{G}_{\mathrm{gas}}$ が，ある排ガス温度 $\mathrm{T}_{\text {out }}$ で同じ值をとる場合の電 力原単位 $\mathrm{W}$ と排熱回収率 $\eta$ の関係を調べた。 まず図 7 から, 排ガス循環酸素燃焼の場合の排ガス温度 $\mathrm{T}_{\text {out }}$ に対す る $\Delta \mathrm{s} / \mathrm{G}_{\mathrm{gas}}$ を決められた電力原単位 $\mathrm{W}$ に対して求め, つぎに図 6 を用いて, 図 7 で求めた $\Delta \mathrm{s} / \mathrm{G}_{\mathrm{gas}}$ と先に設定した 排ガス温度 $\mathrm{T}_{\text {out }}$ に対する排熱回収率を求めた。 このようにして求められた排熱回収率を $\eta_{\mathrm{RC}}$ と定めた.

図 8 は排ガス温度 $\mathrm{T}_{\text {out }}$ に対する $\eta_{\mathrm{RC}}$ の変化である. 排ガス循環型酸素燃焼における電力原単位 $\mathrm{W}$ がパラメタ で, ここでは電力原単位 $\mathrm{W}$ が $0 \sim 0.3 \mathrm{kWh} / \mathrm{m}^{3} \mathrm{~N}$ の場合を示している.

排ガス温度 $\mathrm{T}_{\text {out }}$ が低下し, 炬内温度 $\mathrm{T}_{\mathrm{h}}$ と排ガス温度 $\mathrm{T}_{\text {out }}$ の温度差が大きくなるほど排ガス循環型酸素燃焼と同 一のエントロピー変化 $\Delta \mathrm{s} / \mathrm{G}_{\mathrm{gas}}$ を与える熱循環型高温空気燃焼の排熱回収率 $\eta_{\mathrm{RC}}$ は減少する.

これは，炉内温度 $\mathrm{T}_{\mathrm{h}}$ と排ガス温度 $\mathrm{T}_{\text {out }}$ の温度差が大きくなればなるほど，排熱回収率 $\eta_{\mathrm{RC}}$ が小さくても熱循環 型高温空気燃焼の方が排ガス循環型酸素燃焼よりも有利であることを示している．したがって，図において，あ る与えられた電力原単位 $\mathrm{W}$ の曲線より上側は熱循環型高温空気燃焼の方が排ガス循環型酸素燃焼よりも熱的に 優れている領域であり，逆にこの曲線より下側は，排ガス循環型酸素燃焼の方が熱循環型高温空気燃焼よりも熱 的に優れている領域である. 排ガス循環型酸素燃焼については, 電力原単位 $\mathrm{W}$ が大きくなるほど, 有利な領域が 狭くなることがわかる.

図 8 に示した排ガス循環型酸素燃焼と熱循環型高温空気燃焼の結果は，作動ガスの単位質量を発生させるた めのエントロピー変化 $\Delta \mathrm{s} / \mathrm{G}_{\mathrm{gas}}$ を相互に比較した結果である. しかし，実際には同じ作動ガス $1 \mathrm{~kg}$ でもガス組成 の違いによる比熱の違いにより, 被加熱物へ与えることのできる熱量は大きく異なる．排ガス循環型酸素燃焼に おける作動ガスは $\mathrm{H}_{2} \mathrm{O}$ と $\mathrm{CO}_{2}$ で構成されているが, 熱循環型高温空気燃焼においてはほとんどが $\mathrm{N}_{2}$ と $\mathrm{O}_{2}$ で構成 されている.これらのガスの比熱を比べると, $\mathrm{CO}_{2}, \mathrm{~N}_{2}$ および $\mathrm{O}_{2}$ の比熱は大きく違わないが, $\mathrm{H}_{2} \mathrm{O}$ の比熱はこれ らの 3 種類のガスの約 2 倍大きい. また，各比熱はいずれもガス温度が高くなると大きくなるが，特に $\mathrm{H}_{2} \mathrm{O}$ の場 合, 高温領域における比熱の増加は他の 3 種類のガスよりも大きい.

そこで，作動ガス組成の違いによる加熱能力の違いを考慮するため，排ガス循環型酸素燃焼の作動ガスの平均 比熱を熱循環型高温空気燃焼の作動ガスの平均比熱で割ったものを新たに $\alpha$ として定義した. 次に, 作動ガスの 加熱能力の違いを考慮して排ガス循環型酸素燃焼と熱循環型高温空気燃焼を比較するため, 図 7 に示した排ガス 循環型酸素燃焼における各電力原単位 $\mathrm{W}$ の単位作動流体質量当たりのエントロピー変化 $\Delta \mathrm{s} / \mathrm{G}_{\mathrm{gas}}$ を $\alpha$ で除し, こ の值と同等のエントロピーを生成する熱循環型高温空気燃焼における排熱回収率 $\eta_{\mathrm{RC}}$ を求めた. 図 9 は, 炉内温 


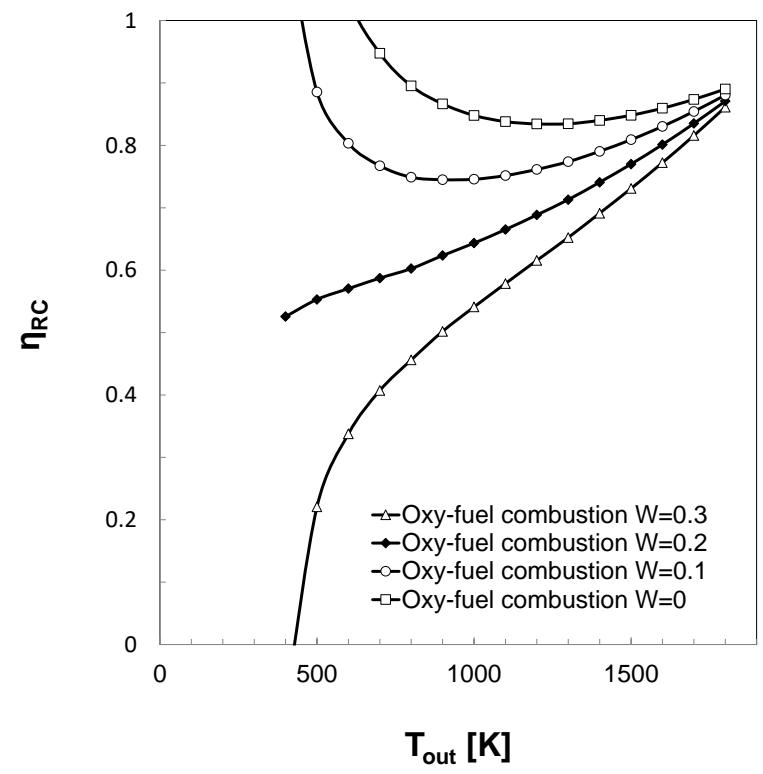

Fig. 9 Effect of outlet gas temperature on $\eta_{\mathrm{RC}}$ for considering the specific heat of the working fluid when the furnace temperature $\mathrm{T}_{\mathrm{h}}=1900 \mathrm{~K}$.

度 $\mathrm{T}_{\mathrm{h}}$ が $1900 \mathrm{~K}$ の時の排熱回収率 $\eta_{\mathrm{RC}}$ を排ガス温度 $\mathrm{T}_{\text {out }}$ に対してプロットしたもので，電力原単位 $\mathrm{W}$ が $0 \sim 0.3$ $\mathrm{kWh} / \mathrm{m}^{3} \mathrm{~N}$ の場合の計算結果である.

各電力原単位 $\mathrm{W}$ に対する排熱回収率 $\eta_{\mathrm{RC}}$ は，比熱の影響を考慮しない場合に比べて大きくなっている.

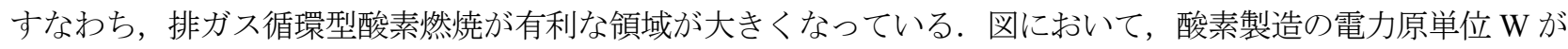
最も大きい $0.3 \mathrm{kWh} / \mathrm{m}^{3} \mathrm{~N}$ の場合でも，排ガス温度 $\mathrm{T}_{\text {out }}$ が $1000 \mathrm{~K}$ において， $\eta_{\mathrm{RC}}$ が約 0.55 以下では排ガス循環型 酸素燃焼の方が熱循環型高温空気燃焼よりも有利になる. 最新の圧力変動吸着法(PSA 法)を用いれば電力原単位 $\mathrm{W}$ は $0.2 \mathrm{kWh} / \mathrm{m}^{3} \mathrm{~N}$ 程度となるが(NEDO, 2011), これくらいの值になると排ガス温度 $\mathrm{T}_{\text {out }}$ のかなりの範囲にわた って排ガス循環型酸素燃焼が熱力学的に有利となっている.さらに熱循環型高温空気燃焼の排熱回収率 $\eta$ は, 炉の形式や大きさによって異なるが，一般にリジェネレーティブバーナ型の排熱回収率 $\eta$ は $0.5 \sim 0.8$ 程度であ り, 熱交換器型の場合は $0.3 \sim 0.5$ 程度である(森田，谷川, 2000). 酸素製造の電力原単位と $\mathrm{W}$ を考慮しなくて良 い場合には，排熱回収率 $\eta_{\mathrm{RC}}$ は常に 0.8 を上回っている. 現状の工業炉の排ガス温度 $\mathrm{T}_{\text {out }}$ が $1000 \sim 1500 \mathrm{~K}$ 付近 であること, 熱循環型高温空気燃焼のリジェネレーティブバーナ方式における排熱回収率 $\eta$ が最大で 0.8 程度で あることを踏まえると, 図 9 の結果は, 排ガス循環型酸素燃焼方式が熱循環型高温空気燃焼と同等かそれ以上の 能力を有していることを示唆している．電力原単位 $\mathrm{W}$ は発電効率と反比例の関係にあるので，発電効率が高く

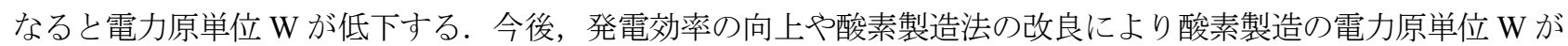
低下していけば，加熱炬において，排ガス循環型酸素燃焼が熱力学的に有利となる場合が多くなる.

\section{4. 結 言}

本研究では，加熱炉を想定して排ガス循環酸素燃焼の高効率燃焼技術としての可能性を熱力学的観点から検討 した，比較においては，通常空気燃焼，熱循環型高温空気燃焼および排ガス循環型酸素燃焼の燃焼過程における エンタルピーおよびエントロピーの変化を調ベた．その結果，熱循環型高温空気燃燒および排ガス循環型酸素燃 焼は，通常空気燃焼に比べて排ガス温度が高温の時はエンタルピーやエントロピーの損失が少ないことが明らか になった．熱循環型高温空気燃焼と排ガス循環型酸素燃焼を比較すると, 酸素製造電力原単位や熱循環型高温空 気燃焼の排熱回収率により優劣が分かれることが分かった。排ガス温度がそれほど高温でないときは，排熱回収 率が高くなくても熱循環型高温空気燃焼の方が排ガス循環型酸素燃焼より熱的に優位である. しかし，排ガス温 度が高温の時は，排ガス循環型酸素燃焼の方が熱循環型高温空気燃焼よりも熱的に優位であることが分かった。 
また，熱循環型高温空気燃焼方式と排ガス循環型酸素燃焼方式の作動ガスの比熱の違いを考慮した場合，すなわ ち炉の加熱能力を考えた場合，排ガス循環型酸素燃燒の有利になる領域が増えることが明らかになった.

\section{文献}

Buhre, B. J. P., Elliott, L. K., Sheng, C. D., Gupta, R. P. and Wall, T. F., Oxy-fuel combustion technology for coal-fired power generation, Progress in energy and combustion science, Vol.31, No.4 (2005), pp.283-307.

Fujimori, T., Hamano, Y. and Sato, J., Radiative heat loss and NOx emission of turbulent jet flames in preheated air up to 1230 K, Proceedings of the Combustion Institute, Vol. 28, No. 1 (2000), pp. 455-461.

Fujimori, T. and Yamada, T., Realization of oxy-fuel combustion for near zero emission power generation, Proceedings of the Combustion Institute, Vol.34, No.2 (2013), pp.2111-2130.

Katsuki, M. and Hasegawa, T., The science and technology of combustion in highly preheated air, Symposium (International) on combustion, Vol. 27, No. 2 (1998), pp. 3135-3146.

Liu, Y., Chen, S., Yang, B., Liu, K. and Zheng, C., First and second thermodynamic-law comparison of biogas MILD oxy-fuel combustion moderated by $\mathrm{CO}_{2}$ or $\mathrm{H}_{2} \mathrm{O}$, Energy Conversion and Management, Vol.106 (2015), pp.625-634.

Liu, $\mathrm{H}$. and Okazaki, K., Simultaneous easy $\mathrm{CO}_{2}$ recovery and drastic reduction of $\mathrm{SOx}$ and $\mathrm{NOx}$ in $\mathrm{O}_{2} / \mathrm{CO}_{2}$ coal combustion with heat recirculation, Fuel, Vol. 82, No.11 (2003), pp. 1427-1436.

丸田薰, 超燃焼 : 燃焼技術の革新による省エネルギーを目指して, 日本燃焼学会誌, Vol.49, No.150 (2007), pp. 246-252.

環境省，地球温暖化対策計画，2016 年 5 月 13 日閣議決定（2016） $<\mathrm{http}: / /$ www.env.go.jp/earth/ondanka/keikaku/onntaikeikaku-zentaiban.pdf >, (参照日 2017 年 5 月 6 日).

森田光宣, 谷川正, 高温空気燃焼技術を応用した高性能工業炉の最適設計, 化学工学論文集, Vol.26. No.2 (2000), pp.227-235.

(国研)新エネルギー・産業技術総合開発機構(NEDO), 高性能工業炉の開発，NEDO プロジェクト実用化ドキュメ ント(2012), <http://www.nedo.go.jp/hyoukabu/articles/201203jifma/index.html>, (参照日 2017 年 5 月 6 日).

(国研)新エネルギー・産業技術総合開発機構(NEDO), 平成 22 年度成果報告書 省エネルギー革新技術開発事業 先導研究 (事前研究) 無機系酸素吸着剤を利用した高効率酸素製造装置の開発の事前研究(2011).

西田耕介, 高城敏美,木下進一, 燃焼におけるエクセルギーの損失過程の解析, 日本機械学会論文集 B 編, Vol.68, No.673 (2002), pp.2643-2649.

日本物理学会編, 物理データ事典, 朝倉書店(2006), p.204.

Tsuji, H., Gupta, A. K., Hasegawa, T., Katsuki, M., Kishimoto, K. and Morita, M., High temperature air combustion: from energy conservation to pollution reduction, CRC press (2003).

吉田邦夫編著, エクセルギー工学, 理論と実際, 共立出版(1999).

吉澤善男, 燃焼の科学と技術, Vol.2 (1994), pp. 277-285.

吉澤善男, エネルギー循環燃焼の熱力学, 日本燃燒学会誌, Vol.50, No.152 (2008), pp.111-117.

\section{References}

Buhre, B. J. P., Elliott, L. K., Sheng, C. D., Gupta, R. P. and Wall, T. F., Oxy-fuel combustion technology for coal-fired power generation, Progress in energy and combustion science, Vol.31, No.4 (2005), pp.283-307.

Fujimori, T., Hamano, Y. and Sato, J., Radiative heat loss and NOx emission of turbulent jet flames in preheated air up to 1230 K, Proceedings of the Combustion Institute, Vol. 28, No. 1 (2000), pp. 455-461.

Fujimori, T. and Yamada, T., Realization of oxyfuel combustion for near zero emission power generation, Proceedings of the Combustion Institute, Vol.34, No.2 (2013), pp.2111-2130.

Katsuki, M. and Hasegawa, T., The science and technology of combustion in highly preheated air, Symposium (International) on combustion, Vol. 27, No. 2 (1998), pp. 3135-3146.

Liu, Y., Chen, S., Yang, B., Liu, K. and Zheng, C., First and second thermodynamic-law comparison of biogas MILD oxy-fuel combustion moderated by $\mathrm{CO}_{2}$ or $\mathrm{H}_{2} \mathrm{O}$, Energy Conversion and Management, Vol.106 (2015), pp.625-634.

Liu, $\mathrm{H}$. and Okazaki, K., Simultaneous easy $\mathrm{CO}_{2}$ recovery and drastic reduction of $\mathrm{SOx}$ and $\mathrm{NOx}$ in $\mathrm{O}_{2} / \mathrm{CO}_{2}$ coal combustion with heat recirculation, Fuel, Vol. 82, No.11 (2003), pp. 1427-1436.

Maruta, K., Innovation of combustion technologies for energy saving, Journal of the Combustion Society of Japan, Journal of 
the Combustion Society of Japan, Vol.49, No.150 (2007), pp. 246-252 (in Japanese).

Ministry of the Environment, Plan for Global Warming Countermeasures, cabinet decision on 13 May 2016 (2016), online in Japanese, available from <http://www.env.go.jp/earth/ondanka/keikaku/onntaikeikaku-zentaiban.pdf > (accessed on 6 May , 2017) (in Japanese).

Morita, M. and Tanigawa, T., Optimal design for high performance industrial furnace applied high temperature air combustion technology, Kagaku Kogaku Ronbunshu, Vol.26, No.2 (2000), pp.227-235 (in Japanese).

New Energy and Industrial Technology Development Organization (NEDO), Development of Highly efficient industrial furnace, NEDO Project success stories (2012), online in Japanese, available from

$<$ http://www.nedo.go.jp/hyoukabu/articles/201203jifma/index.html> (accessed on 6 May, 2017) (in Japanese).

New Energy and Industrial Technology Development Organization (NEDO), Research and Development Program for Innovative Energy Efficiency Technology, Exploratory research phase (Preliminary research), "Preliminary research on development of a highly-efficient oxygen production instrument using perovskite-type oxygen sorbents", (FY2010) Final Report (2011) (in Japanese).

Nishida, K., Takagi, T. and Kinoshita, S., Process analysis of exergy loss in combustion field, Transactions of the Japan Society of Mechanical Engineers, Series B, Vol.68, No.673 (2002), pp. 2643-2649 (in Japanese).

The Physical Society of Japan (JPS) ed., Physical data dictionary, Asakura shoten (2006), p.204 (in Japanese).

Tsuji, H., Gupta, A. K., Hasegawa, T., Katsuki, M., Kishimoto, K. and Morita, M., High temperature air combustion: from energy conservation to pollution reduction, CRC press (2003).

Yoshida, S. ed., Exergy: Theory and practice, Kyoritsu Shuppan (1999) (in Japanese).

Yoshizawa, Y., Official publication of the Association for Combustion and Environmental Sciences, Vol.2 (1994), pp. 277-285 (in Japanese).

Yoshizawa, Y., Thermodynamics of Combustion with Energy Recirculation, Journal of the Combustion Society of Japan, Vol.50, No.152 (2008), pp.111-117 (in Japanese). 